\title{
Methane Production From Industrial Hemp
}

\author{
Aleksandrs M. Adamovics, \\ Dr.Sc.(Agr.), adamovics.aleksandrs@1lu.lv; \\ Semjons A. Ivanovs, \\ Dr.Sc.(Eng.);
}

\author{
Vilis S. Dubrovskis, \\ Dr.Sc.(Eng.)
}

Latvia University of Life Sciences and Technologies, Jelgava, Latvia

\begin{abstract}
Due to the increasing shortage of fossil fuels, the use of alternative energy sources is becoming even more popular. In Latvia, maize is predominantly used for the production of biogas, and other crops are being studied for this purpose. (Research purpose) To study the productivity of industrial hemp varieties (Cannabis sativa L.) and the possibility of obtaining biogas from hemp. (Materials and methods) Field experiments on hemp productivity were carried out on sod calcareous, heavy dusty sand clay soils in 2012-2014. Ten industrial varieties of hemp - 'Bialobrzeskie', 'Futura 75', 'Fedora 17', 'Santhica 27', 'Beniko', 'Ferimon', 'Epsilon 68', 'Tygra', 'Wojko', and 'Uso 31' - were sown with a seeding rate of 50 kilogram per hectare at the background of fertilizers: nitrogen - 120, phosphoric oxide - 90, potassium oxide 150 kilogram per hectare. Hemp was sown on 10-square meter plots in mid-May, in triplicate. Hemp was harvested at the beginning of seed ripening phase. The whole crop of green mass was calculated on a completely dry matter. The fermentation process for the production of biogas, the average yield of methane, and other parameters were studied in the Laboratory of Bioenergetics of the Latvia University of Life Sciences and Technologies, using small-sized bioreactors. (Results and discussion) The dry matter yield of hemp obtained in the agro-climatic conditions of Latvia averaged 13.3217.78 tons per hectare. For an average of three years (2012-2014), higher yields of dry matter were obtained from the varieties of 'Futura 75' (17.76 tons per hectare) and 'Tygra' (16.31 tons per hectare). The average amount of methane obtained from the 'Uso 31' leaves was 0.365 litre from one gramme of dry organic matter, which is a very good result as compared to other energy crops, for example, corn silage (0.319-0.330 litre from one gramme of dry organic matter in Latvia). (Conclusions) The research has demonstrated that hemp can be successfully used to produce biogas, and hemp leaves are the most suitable starting material.
\end{abstract}

Keywords: industrial hemp (Cannabis sativa L.), productivity, methane, biogas, bioreactor.

For citation: Adamovics A.M., Ivanovs S.A., Dubrovskis V.S. Methane production from industrial hemp. Sel'skokhozyaystvennye mashiny i tekhnologii. 2019. Vol. 13. N2. 20-26. DOI 10.22314/2073-7599-2018-13-2-2026 (In English).

\section{Производство метана из промышленной конопли}

\author{
Александр Михайлович Адамовичс, \\ доктор сельскохозяйственных наук, \\ adamovics.aleksandrs@1lu.lv;
}

\author{
Семен Агафонович Ивановс, \\ доктор инженерных наук; \\ Вилис Станиславович Дубровскис, \\ доктор инженерных наук
}

Латвийский университет естественных наук и технологий, г. Елгава, Латвия

Реферат. Из-за растущей нехватки ископаемого топлива использование альтернативных источников энергии ста-
новится все более популярным. В Латвии кукуруза является доминирующей культурой, используемой для про-
изводства биогаза, однако ведутся также исследования по использованию других энергокультур. (Цель исследо-
вания) Изучить продуктивность сортов промышленной конопли (Cannabis sativa L.) и возжности получения из
нее биогаза. (Maтериаль и методы) Полевые опыты по изучению продуктивности конопли проводили в $2012-$
2014 гг. на плодородных дерново-карбонатных, среднетяжелых почвах. Десять промышленных сортов конопли -
Bialobrzeskie, Futura 75, Fedora 17, Santhica 27, Beniko, Ferimon, Ерsilon 68, Туgra, Wojkо и Uso 31 высевали с нор-
мой высева семян 50 килограммов на гектар на фоне удобрений: азота - 120, оксида фосфора - 90 , оксида калия -
150 килограммов на гектар. Коноплю сеяли в середине мая, на учетных делянках площадью 10 квадратных метров,
в трехкратной повторности. Урожай убирали в начале фазы созревания семян. Всю зеленую массу пересчитали на 
абсолютно сухое вещество. Процесс брожения для производства биогаза, средний выход метана и другие параметры изучали в лаборатории биоэенеретики Латвийского университета естественных наук и технологий, используя малогабаритные биореакторы. (Результаты и обсуждение) Урожайность сухого вещества конопли, полученного в агроклиматических условиях Латвии, в среднем составила 13,32-17,78 тонны с гектара. В среднем за три года (2012-2014 гг.) более высокие урожаи сухого вещества получили от сортов Futura 75 - 17,76 тонны с гектара и Tygra - 16,31 тонны с гектара. Среднее количество метана, полученного из листьев Uso 31 составило 0,365 литра на грамм сухого органического вещества. Хороший результат по сравнению с другими энергетическими культурами, например кукурузным силосом, показатель которого в Латвии равен 0,319-0,330 литра на грамм сухого органического вещества. (Bblвoдbl) Результаты исследований показали, что коноплю, особенно ее листья, с успехом можно использовать для производства биогаза.

Ключевые слова: промышленная конопля (Cannabis sativa L.), продуктивность, метан, биогаз, биореактор.

Ш Для цитирования: Адамовичс А.М., Ивановс С.А., Дубровскис В.С. Производство метана из промышленной конопли // Сельскохозяйственные машины и технологии. 2019. Т. 13. N2. C. 20-26. DOI 10.22314/20737599-2018-13-2-20-26.

I ndustrial hemp (Cannabis sativa L.) is one of the oldest home-grown and most versatile plants, and it has been cultivated over a long time period. In 19th century, its cultivation thereof in Europe declined, while recently, it has attracted interest again [1]. Nowadays, industrial hemp has become important as a crop used for biomass production. Environmental concern and recent shortage of wood fibre have renewed utilisation of hemp for wide range of industrial products, including textiles, paper, and composite wood products [2].

Analyses of the latest trends in hemp cultivation and use as well as experimental results allow concluding that hemp cultivation and processing in Latvia are very perspective, since this plant is fast-growing and suitable for Latvia's agro-climatic conditions.

Recently in Latvia, the number of industrial hemp growers and the area of cultivated land both have increased, and, in line with the data provided by the Association of Industrial Hemp of Latvia, hemp plantations in 2018 occupied approximately 1100 ha, showing growing interest in this agricultural sphere.

The amount of biogas obtained from various raw materials differs [3, 4]. Several researchers, when studying similar raw materials, have come to different conclusions, and the results depend upon substrate, conditions under which anaerobe process takes place, microorganisms content, and other factors [5, 6]. One of the key factors influencing the production of biogas is the content of organic matter, especially the content of three main organics matter [7, 8] groups: carbohydrates, proteins, and lipids.

Biogas may be produced from various waste, e.g., pig manure - with yielding of $0.34-0.68 \mathrm{~m}^{3} / \mathrm{kg}$ dry organic matter (DOM), cattle manure $\left(0.2-0.4 \mathrm{~m}^{3} / \mathrm{kg}\right.$ DOM), poultry manure $\left(0.37-0.64 \mathrm{~m}^{3} / \mathrm{kg} \mathrm{DOM}\right)$, dairy produce waste $\left(0.62 \mathrm{~m}^{3} / \mathrm{kg}\right.$ DOM $)$, and sewage sludge (0.2-0.6 $\mathrm{m}^{3} / \mathrm{kg} \mathrm{DOM).}$

Various kinds of straw can also be one of the raw materials used to produce biogas. Usually, they are used as bedding in livestock and poultry housings, and together with manure it is a cheap material.

Also freshly mown grass may be used for biogas production. Grasses vary, and the biogas yielded from them will differ as well. Theoretically, legumes should produce more biogas compared to grasses. Moreover, soil in which and climatic conditions under which grass has grown are of great significance. The average content of grass dry matter comprises $12-25 \%$, the content of DOM $-85-93 \%$.

Unfortunately, literature sources only sometimes indicate the particular grass used, and thus, the data taken mainly from German researches, not always are suitable for use under Latvia's conditions. As it can be seen in tables, data are contradictory, and in several cases, it seems that authors have mistaken biogas for methane. In Latvia, the potential of biogas production from various grasses has been studied only in few researches, and biogas yield from hemp has been investigated only once. Moreover, information acquired in foreign researches is very poor [9-15]. Currently, Lund University in Sweden is conducting a hemp research; within the framework of it, rather good results have been acquired, and it has been concluded that industrial hemp grown under climatic conditions of south Sweden (Skone) is one of the energy plants that is the most suitable for biogas production

THE RESEARCH PURPOSE is to investigate the productivity of industrial hemp varieties (Cannabis sativa L.) and the possibility of obtaining biogas from it.

Materials AND Methods. Field trials were carried out in the Study and Research Farm "Peterlauki" (56 53' $\mathrm{N}, 23^{\circ} 71^{\prime} \mathrm{E}$ ) of the Latvia University of Life Sciences and Technologies in 2012-2014. Ten industrial hemp (Cannabis sativa L.) cultivars - 'Bialobrzeskie', 'Futura 75', 'Fedora 17', 'Santhica 27', 'Beniko', 'Ferimon', 'Epsilon 68', 'Tygra', 'Wojko' and 'Uso 31' - were sown in the sod calcareous soil Luvisols (according to FAO classification); granulometric composition: heavy dusty 
sand clay. Soil agrochemical parameters: $\mathrm{pH} \mathrm{KCl} 6.7$ (LVS ISO 10390: 2006); organic matter content: $21 \mathrm{~g} / \mathrm{kg}$ (by Tyurin method, LV ST ZM 80-91), the phosphorus (P) and potassium (K) level $-52 \mathrm{mg} / \mathrm{kg}$ and $128 \mathrm{mg} / \mathrm{kg}$, respectively (according to Egner-Rhym method, LV ST ZM 82-97). Total seeding rate comprised $50 \mathrm{~kg} / \mathrm{ha}$. The plots were fertilised as follows: $\mathrm{N}-120, \mathrm{P}_{2} \mathrm{O}_{5}-90$, $\mathrm{K}_{2} \mathrm{O}-150 \mathrm{~kg} / \mathrm{ha}$. Hemp was sown in $10 \mathrm{~m}^{2}$ plots by using the plot sowing machine "Wintersteiger", triplicate, in the middle of May. Hemp was harvested using the small mower "MF-70" when first matured seed appeared (Fig. 1). Biometrical indices of hemp seedlings, the height and stem diameter in the middle of harvesting time, the amount of green and dry above-ground mass, and fibre content were evaluated.
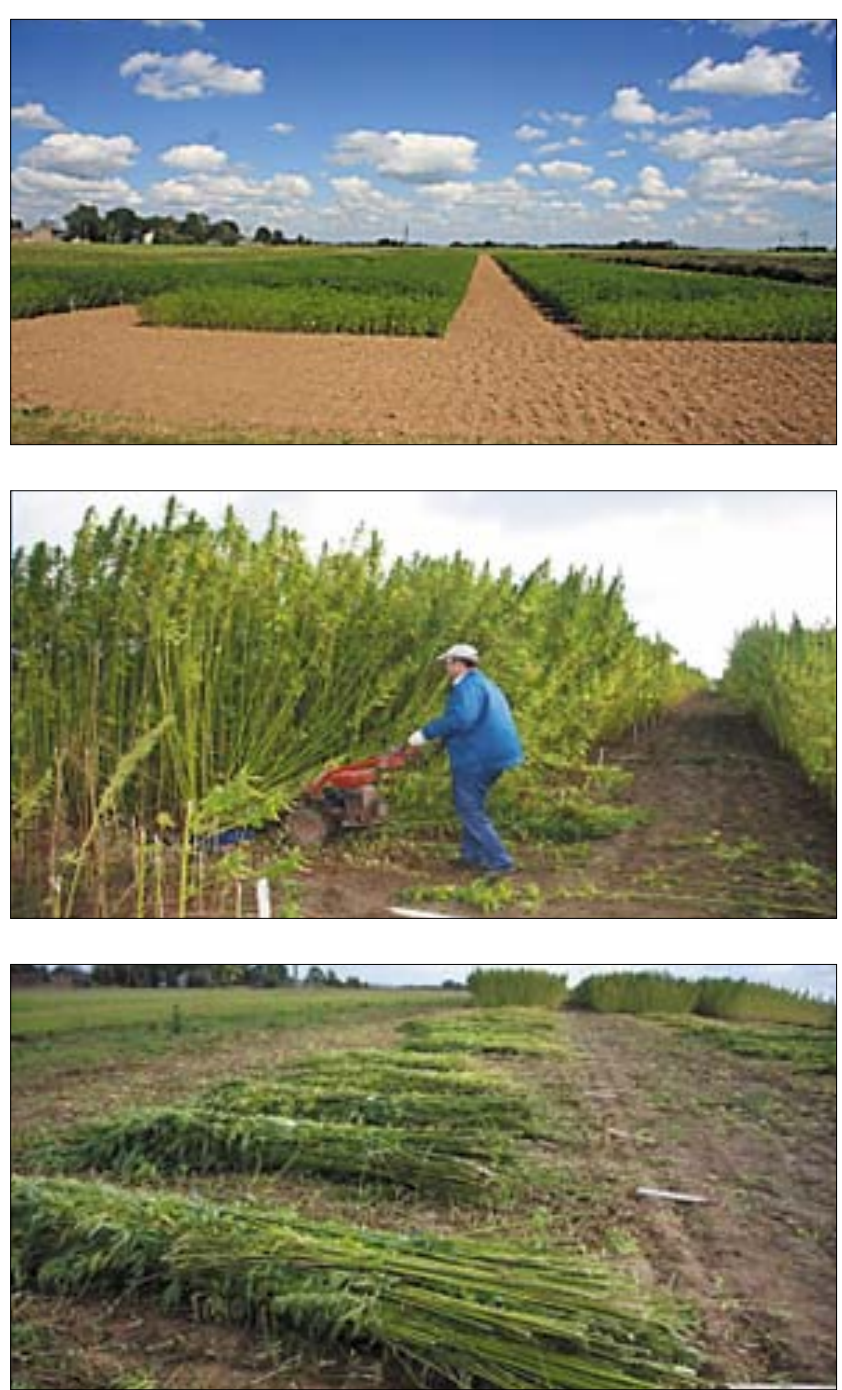

Fig. 1. Field trials of hemp at the research and study farm 'Peterlauki' of the Latvia University of life sciences and technologies

The research was conducted with industrial hemp (Cannabis sativa L.) that was taken from trial plots. The samples were tested with analyses necessary for successful anaerobic fermentation (AF) process complete dry matter, ash, and organic dry matter were measured. Basing on the results of the analyses, the necessary quantity of hemp was calculated $(100 \mathrm{~g})$, which, afterwards, was filled in the bioreactors B2, B3 and B4 together with yeast $(2000 \mathrm{~g})$ and water $(1500 \mathrm{~g})$. The remaining biogas potential of yeast was verified by fermenting it in the bioreactor B1. Substrate formation proportions were equal in all bioreactors: $2000 \mathrm{~g}$ of yeast, $100 \mathrm{~g}$ of hemp to be fermented, and $1500 \mathrm{~g}$ of warm water. Hemp was chopped - the length of pieces in coarse chopping was $1-2 \mathrm{~cm}$, while fine chopping that was made with electric chopper produced $1-5 \mathrm{~mm}$ pieces. Each substance was carefully weighted before filling it in bioreactors. Fermentation took place within single filling regime till biogas was not forming anymore. Each day, all parameters necessary to control the process - gas amount and content, $\mathrm{pH}$, pressure, temperature in room and bioreactors - were registered in a research journal. Also, digestate was weighted and the content thereof was analysed. Substrate in bioreactors was mixed with a specific devise operated by a mobile perforator. (Note: the quantity of yeast depended on the condition that such a quantity can be taken out of a continuously working bioreactor, thus ensuring equal conditions in all bioreactors. The condition that there was sufficiently much yeast, notably speeded up the start of a stable AF process.

Biogas researches were conducted with industrial hemp cultivars 'Futura 75' and 'Uso 31'.

The amount of biogas obtained was researched using a laboratory device consisting of four 51 bioreactors (Fig. 2). Each bioreactor was equipped with the temperature maintenance and gas collection devices and an automatic registration apparatus. $\mathrm{pH}$ and pressure were controlled visually, afterwards registering parameters thereof in computer. Observations were made at $38 \pm 1^{\circ} \mathrm{C}$ temperature under a single filling regime.

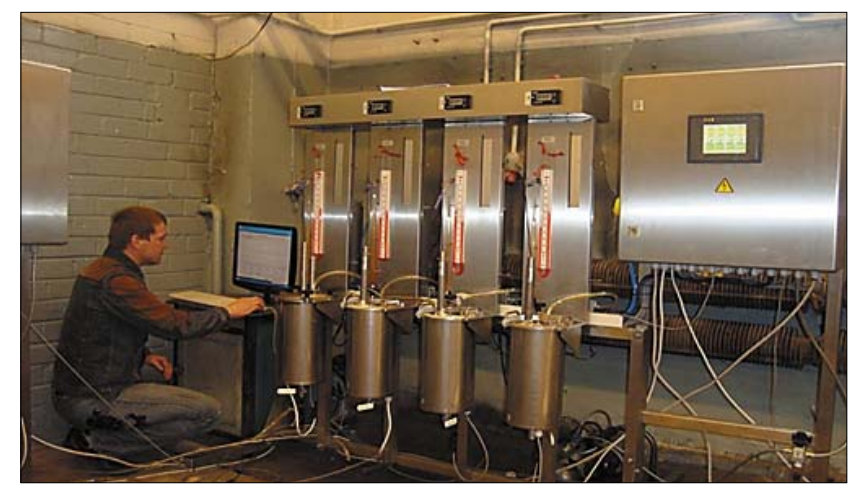

Fig. 2. A laboratory device consisting of four 5 l bioreactors

With the aim to speed up the start of the process, the yeast for 51 bioreactors was taken from a working bioreactor. Microbiological yeast was fermented with cattle manure that was added in each bioreactor $(15 \%$ of total substrate). For substrate and dry matter of each substance, ash and organic dry matter were cleared 
out before filling them in bioreactors. Measurement precision was \pm 0.02 for $\mathrm{pH}, \pm 0.00251$ for gas, and $\pm 0.1^{\circ} \mathrm{C}$ for temperature. Biogas content was measured periodically by finding out the content of $\mathrm{CH}_{4}, \mathrm{CO}_{2}, \mathrm{O}_{2}$, and $\mathrm{H}_{2} \mathrm{~S}$.

Complete dry matter was measured with the dry matter weights "Shimazu" at the temperature of $120^{\circ} \mathrm{C}$, the content of organic dry matter was determined by drying the samples under a particular programme at $550^{\circ} \mathrm{C}$ in the oven "Nabertherm". Gas content was measured with gas analyser "GA 2000", thus finding out the content of methane, oxygen, carbon dioxide, and hydrogen sulphide in biogas, as well as the pressure and normal gas volume. Weighting was made with the weights "Kern FKB 16KO2"; pH was measured with the $\mathrm{pH}$ meter "PP-50" with accessories (stationery).

A mean hemp sample was taken, and its content was studied basing on standardised methodologies in compliance with ISO 6496:1999 in the Bioenergetics Laboratory of Latvia University of Life Sciences and Technologies. Mean sample and yeast of each raw material group were investigated to determine full dry matter, organic dry matter, and the content of main

\begin{tabular}{|l|c|c|c|c|}
\hline \multicolumn{5}{|c|}{$\begin{array}{c}\text { Table 2 } \\
\text { BIOMASS DRY MATER YIELD FROM DIFFERENT INDUSTRIAL HEMP } \\
\text { CULTIVAR T/HA (2012-2014) }\end{array}$} \\
\hline \multicolumn{1}{|c|}{ Hemp cultivars } & $\mathbf{2 0 1 2}$ & $\mathbf{2 0 1 3}$ & $\mathbf{2 0 1 4}$ & Average \\
\hline Bialobrzeskie & 11.95 & 12,91 & 15.56 & 13.47 \\
\hline Futura 75 & 21.33 & 17.14 & 14.81 & 17.76 \\
\hline Fedora 17 & 18.23 & 13.32 & 12.78 & 14.78 \\
\hline Santhica 27 & 17.39 & 11.57 & 13.47 & 14.14 \\
\hline Beniko & 19.27 & 13.30 & 11.96 & 14.84 \\
\hline Ferimon & 18.59 & 13.09 & 12.93 & 14.87 \\
\hline Epsilon 68 & 12.89 & 18.47 & 14.47 & 15.28 \\
\hline Tygra & 20.87 & 14.66 & 13.40 & 16.31 \\
\hline Wojko & 19.91 & 14.83 & 11.79 & 15.51 \\
\hline Uso 31 & 17.38 & 11,40 & 11.98 & 13.59 \\
\hline Average & 17.78 & 14.07 & 13.32 & 15.06 \\
\hline LSD 0.05 variety & & 3.15 \\
\hline LSD 0.05 year & \multicolumn{5}{|c|}{1.92} \\
\hline $\begin{array}{l}\text { LSD 0.05 interaction } \\
\text { between variety and } \\
\text { year }\end{array}$ & & 4.03 \\
\hline
\end{tabular}

\begin{tabular}{|c|c|c|c|c|c|c|c|c|}
\hline \multicolumn{9}{|c|}{ ANALYSIS OF RAW MATERIAL } \\
\hline Raw/digester & $\mathbf{p H}$ & TS*, \% & TS*,g & Ash, \% & DOM*, \% & DOM*, g & Weight, g & $\begin{array}{c}\text { Total } \\
\text { weight, } g\end{array}$ \\
\hline Inoculum, B1-1 & 7.29 & 3.40 & 68.0 & 23.1 & 76.89 & 52.29 & 3500 & 52.29 \\
\hline Coarse Uso 31, B1-2 & 7.19 & 63.97 & 63.97 & 7.15 & 92.85 & 59.4 & 3600 & 111.69 \\
\hline Fine Uso 31, B1-3 & 7.22 & 55.13 & 55.13 & 7.51 & 92.49 & 50.99 & 3600 & 103.28 \\
\hline Uso 31 leaves, B1-4 & 7.25 & 62.96 & 62.9 & 16.1 & 83.84 & 52.79 & 3600 & 105.08 \\
\hline
\end{tabular}

elements; moreover, each sample was weighted carefully and the yeast mixed with the rest of the mass. The same yeast was used for all four samples - digestate from the continuously working bioreactor. The bioreactors of 0.71 were filled with $20 \mathrm{~g}$ of hemp and 0.51 of yeast (weight was registered with a $0.2 \mathrm{~g}$ precision). All bioreactors (altered standard containers) were connected with gas accumulation bags and taps, placed in the oven under the temperature of $38 \pm 0.5^{\circ} \mathrm{C}$. The amount and content of gas produced were measured every day; bioreactors were shaken with the same frequency thus mixing the substrate and reducing the floating layer.

Results and discussion. The yield of hemp dry matter (DM) obtained in the field trials under agro-climatic conditions of Latvia was 13.32-17.78 t/ha (15.06 t/ha on average). Cultivation year and selected variety notably affected hemp biomass yield (Table 1). In 2012, depending on the variety, a notably higher yield of absolute DM biomass (on average $17.78 \mathrm{t} / \mathrm{ha}$ ) was obtained from the cultivars 'Futura 75' (21.33 t/ha), 'Tygra' (20.87 t/ha), 'Beniko' (19.27 t/ha), and 'Wojko' (19.91 t/ha). On average in three years (2012-2014), relatively higher
DM yields were obtained from varieties 'Futura 75' (17.76 t/ha) and 'Tygra' (16.31 t/ha).

Statistical assessment showed that meteorological conditions present during the growing season influenced the total volume of dry biomass yield.

The measurements obtained were summarised in tables and served as a base to calculate the potential for producing biogas and methane in each bioreactor. Calculations were made bearing in mind also the volume of gas produced in the control bioreactor (the one from which yeast was taken) (Table 2).

Hemp cultivar 'Uso 31' was taken from the trial field on 24 August 2013, on a very dry and sunny day, and on 4 September 2013, it was filled in a bioreactor. This condition as well as the condition that this hemp was stored in suitable premises may explain the comparatively high content of dry matter and dry organic matter. Anaerobe fermentation lasted for 53 days. The results of digestate analyses are shown in Table 3.

In all bioreactors, gas was appearing evenly, already within the first days, except the control bioreactor, which contained only yeast and water. In this reactor, 


\begin{tabular}{|c|c|c|c|c|c|c|c|}
\hline \multicolumn{8}{|c|}{ RESULTS OF DIGESTATE ANALYSES } \\
\hline Raw / digester & pH & TS*, $\%$ & TS*, g & Ash, $\%$ & DOM*, \% & DOM* $^{*}, \mathrm{~g}$ & Weight, g \\
\hline Inoculum, B1-1 & 7.32 & 2.18 & 66.17 & 25.62 & 74.38 & 49.22 & 3028 \\
\hline Coarse Uso 31, B1-2 & 7.41 & 2.62 & 79.38 & 23.01 & 76.99 & 61.12 & 3030 \\
\hline Fine Uso 31, B1-3 & 7.36 & 2.41 & 75.19 & 21.58 & 78.42 & 58.96 & 3120 \\
\hline Uso 31 leaves, B1-4 & 7.48 & 2.56 & 81.10 & 28.14 & 71.86 & 58.28 & 3168 \\
\hline
\end{tabular}

only a small amount of gas was produced, which means that yeast contained a very small quantity of not decomposed organic matter that is consumed by bacteria. Biogas and methane yields produced in all bioreactors are shown in Table 4.

The highest amount of biogas and methane was produced in the bioreactor B1-4, which fermented chopped leaves. This may be explained by the fact that

\begin{tabular}{|l|c|c|c|}
\hline \multicolumn{4}{|c|}{ BIOGAS AND METHANE PRODUCED FROM HEMP CULTIVAR 'USO 31' } \\
\hline Raw/digester & Biogas, I & $\begin{array}{c}\text { Biogas, } \\
\text { l/g DOM }\end{array}$ & $\begin{array}{c}\text { Methane, } \\
\text { I/g DOM }\end{array}$ \\
\hline Inoculum, B1-1 & 0.6 & 0.011 & 0.003 \\
\hline Coarse Uso 31, B1-2 & 22.93 & 0.376 & 0.195 \\
\hline Fine Uso 31, B1-3 & 22.58 & 0.431 & 0.230 \\
\hline Uso 31 leaves, B1-4 & 30.32 & 0.563 & 0.334 \\
\hline
\end{tabular}

subtracted from the total volume acquired in each bioreactor). Also, the average indicators of each group were calculated. The results of raw material analyses were summarised in Table 5.

As it can be seen in Table 5, hemp has high contents of dry matter (41.62-62.96\%) and organic dry matter. This may be explained by the fact that hemp was harvested in dry weather and kept in dry premises before chopping. The results of digestate analyses are presented in Table 6.

The biogas and methane volumes yielded from the coarse-chopped 'Futura 75' are presented in Table 7.

The biogas and methane volumes yielded from the fine-chopped hemp cultivar 'Futura 75' are shown in Table 8 .

The biogas and methane yields obtained from the fine-chopped 'Uso 31' are summarised in Table 9.

\begin{tabular}{|l|c|c|c|c|c|c|c|c|}
\hline \multicolumn{10}{|c|}{ Reable 5 OF RAW MATERIAL ANALYSES } \\
\hline \multicolumn{1}{|c|}{ Raw/digester } & pH subs. & TS*, \% & TS*, g & Ash, \% & DOM*, \% & DOM*, g & Weight, g & $\begin{array}{c}\text { Total } \\
\text { DOM*, g }\end{array}$ \\
\hline Coarse Futura 75, R2-4 & 7.31 & 41.62 & 8.32 & 9.1 & 90.9 & 7.57 & 520 & 16.33 \\
\hline Inoculum, R1, R16 & 7.29 & 2.35 & 11.75 & 25.44 & 74.6 & 8.76 & 500 & 8.76 \\
\hline Fine Futura 75, R5-8 & 7.32 & 43.39 & 8.68 & 4.5 & 95.5 & 8.29 & 520 & 17.05 \\
\hline Fine Uso 31, R9-12 & 7.28 & 55.13 & 11.03 & 7.51 & 92.5 & 10.20 & 520 & 18.96 \\
\hline Uso 31 leaves, R13-15 & 7.25 & 62.96 & 12.59 & 16.16 & 83.8 & 10.56 & 520 & 19.32 \\
\hline
\end{tabular}

\begin{tabular}{|l|c|c|c|c|c|c|c|}
\hline \multicolumn{7}{|c|}{ AverAGE RESULTS OF DIGESTATE ANALYSES } \\
\hline \multicolumn{1}{|c|}{ Raw/digester } & pH substr. & TS*, $\%$ & TS*, $\mathbf{g}$ & Ash, $\%$ & DOM* $\%$ & DOM*, g & Weight, $\mathbf{g}$ \\
\hline Coarse Futura 75, R2-4 & 7.17 & 3.58 & 18.19 & 23.76 & 76.24 & 13.87 & 508.23 .1 \\
\hline Inoculum, R1, R16 & 7.45 & 2.30 & 11.47 & 26.48 & 73.52 & 8.44 & 498.9 \\
\hline Fine Futura 75, R5-8 & 7.08 & 3.24 & 16.56 & 22.03 & 77.97 & 12.91 & 511.1 \\
\hline Fine USO 31, R9-12 & 7.06 & 3.06 & 15.61 & 21.37 & 78.73 & 12.29 & 510.0 \\
\hline USO 31 leaves, R13-15 & 7.29 & 3.39 & 17.3 & 29.26 & 70.74 & 12.24 & 510.2 \\
\hline *Abbreviations: TS - total solids; DOM - dry organic matter & & & & &
\end{tabular}

hemp stems contain comparatively more cellulose and lignin, which is difficult to degrade by bacteria.

When calculating the volumes of biogas and methane obtained, also the biogas and methane produced from control yeast were taken into account (they were
The biogas and methane yields obtained from chopped 'Uso 31' leaves are shown in Table 10.

The average biogas and methane volumes yielded from various hemps are summarised in Table 11. The results suggest that the highest amount of methane 
Table 7

BIOGAS AND METHANE YIELDS FROM THE COARSE-CHOPPED HEMP CULTIVAR 'FUTURA 75

\begin{tabular}{|l|c|c|c|}
\hline \multicolumn{1}{|c|}{ Raw/digester } & Biogas, I & $\begin{array}{c}\text { Biogas, } \\
\text { l/g DOM }\end{array}$ & $\begin{array}{c}\text { Methane, } \\
\text { l/g DOM }\end{array}$ \\
\hline Coarse Futura 75, R2 & 2.8 & 0.370 & 0.177 \\
\hline Coarse Futura 75, R3 & 2.7 & 0.357 & 0.172 \\
\hline Coarse Futura 75, R4 & 2.9 & 0.383 & 0.185 \\
\hline Inoculum, R1 & 0.1 & 0.011 & 0.002 \\
\hline
\end{tabular}

Table 8

BIOGAS AND METHANE YIELDS FROM THE FINE-CHOPPED HEMP CULTIVAR 'FUTURA 75'

\begin{tabular}{|l|c|c|c|}
\hline \multicolumn{1}{|c|}{ Raw/digester } & Biogas, I & $\begin{array}{c}\text { Biogas, l/g } \\
\text { DOM }\end{array}$ & $\begin{array}{c}\text { Methane, } \\
\text { l/g DOM }\end{array}$ \\
\hline Fine Futura 75, R5 & 4.0 & 0.481 & 0.245 \\
\hline Fine Futura 75, R6 & 4.0 & 0.482 & 0.246 \\
\hline Fine Futura 75, R7 & 3.9 & 0.470 & 0.240 \\
\hline Fine Futura 75, R8 & 4.1 & 0.530 & 0.270 \\
\hline Inoculum, R1 & 0.1 & 0.011 & 0.002 \\
\hline
\end{tabular}

BIOGAS AND METHANE YIELDS FROM THE COARSE-CHOPPED HEMP

\begin{tabular}{|l|c|c|c|}
\hline \multicolumn{1}{|c|}{ Raw/digester } & Biogas, I & $\begin{array}{c}\text { Biogas, l/g } \\
\text { DOM }\end{array}$ & $\begin{array}{c}\text { Methane, } \\
\text { I/g DOM }\end{array}$ \\
\hline Fine Uso 31, R9 & 4.5 & 0.441 & 0.226 \\
\hline Fine Uso 31, R10 & 4.1 & 0.402 & 0.205 \\
\hline Fine Uso 31, R11 & 4.3 & 0.422 & 0.216 \\
\hline Fine Uso 31, R12 & 4.3 & 0.421 & 0.215 \\
\hline Inoculum, R1 & 0.1 & 0.011 & 0.002 \\
\hline
\end{tabular}

was obtained from chopped 'Uso 31' leaves, which may be due to the fact that they contained more juice and less cellulose and lignin compared to stems. Comparison to same-fineness hemp cultivars 'Futura 75' and 'Uso 31' demonstrated that 'Futura 75' produced more methane.

\begin{tabular}{|l|c|c|c|}
\hline \multicolumn{4}{|c|}{$\begin{array}{c}\text { Table 10 } \\
\text { BIOGAS AND METHANE YIELDS FROM THE HEMP CULTIVAR 'USO 31' } \\
\text { LEAVES }\end{array}$} \\
\hline \multicolumn{1}{|c|}{ Raw/digester } & Biogas, I & $\begin{array}{c}\text { Biogas, //g } \\
\text { DOM }\end{array}$ & $\begin{array}{c}\text { Methane, } \\
\text { l/g DOM }\end{array}$ \\
\hline Leaves Uso 31, R13 & 6.7 & 0.634 & 0.375 \\
\hline Leaves Uso 31, R14 & 6.3 & 0.507 & 0.354 \\
\hline Leaves Uso 31, R15 & 6.5 & 0.616 & 0.365 \\
\hline Inoculum, R1 & 0.1 & 0.011 & 0.002 \\
\hline
\end{tabular}

The average amount of methane obtained from 'Uso 31 ' leaves $(0.3650 .010 \mathrm{l} / \mathrm{g} \mathrm{DOM})$ is a very good result as compared to other energy crops, for example, maize silage (0.319-0.330 1/g DOM in Latvia). Studies on 'Futura 75' resulted in 0.234-0.290 1/g DOM of methane. Research on the influence of harvesting time on the methane output allowed concluding that this influence is insignificant - only slightly smaller than that on the hemp harvested in October [14]. A more notable effect was left by pre-processing, and, if samples were chopped into $1-2 \mathrm{~mm}$ pieces, a total of $0.290 \mathrm{l} / \mathrm{g}$ DOM of methane was obtained.

\section{Conclusions}

1. Under agro-climatic conditions of Latvia, varieties of industrial hemp provide on average $15.0 \mathrm{t} / \mathrm{ha}$ of dry matter yield. The highest biomass yield during trial years was obtained from the cultivars 'Futura 75 ' and 'Tygra': $17.76 \mathrm{t} / \mathrm{ha}$ and $16.31 \mathrm{t} / \mathrm{ha}$ respectively. According to the data, a conclusion can be drawn that the growing season and the selected industrial hemp variety had a significant $(\mathrm{p}<0.05)$ effect on hemp yield.

2 . The research suggests that the biomass of hemp grown in Latvia provides high methane extraction; therefore it can be used for biogas production.

3. A larger methane outcome was obtained from finely chopped hemp stalks and leaves.

4. Influence of hemp harvesting time of two weeks on the methane output is insignificant.

\begin{tabular}{|l|c|c|c|c|c|}
\hline \multicolumn{7}{|c|}{ Average biogas AND METHANE Volumes YIELDED FROM HEMP } \\
\hline \multicolumn{1}{|c|}{ Raw/digester } & Biogas, I & Biogas, I/g DOM & Methane, \% & $\begin{array}{c}\text { Methane, I } \\
\text { (without } \\
\text { inoculum) }\end{array}$ & $\begin{array}{c}\text { Methane, } \\
\text { I/g DOM added }\end{array}$ \\
\hline Inoculum & 0.1 & 0.011 & 20.3 & 0.02 & 0.002 \\
\hline Coarse Futura 75, R2-4 & 2.8 & 0.370 & 48.21 & 1.33 & $0.177 \pm 0.007$ \\
\hline Fine Futura 75, R5-8 & 4.0 & 0.482 & 51.03 & 2.036 & $0.246 \pm 0.023$ \\
\hline Fine USO 31, R9-12 & 4.3 & 0.422 & 51.18 & 2.206 & $0.216 \pm 0.011$ \\
\hline Uso 31 leaves, R13-15 & 6.5 & 0.616 & 59.25 & 3.852 & $0.365 \pm 0.01$ \\
\hline
\end{tabular}

\section{REFERENCES}

1. Kortekaas S. Contribution of extractives to methanogenic toxicity of hemp black liquor. Journal of Fermentation and Bioengineering. 1995. 80(4). 383-388 (In English).

2. Feasibility of Industrial Hemp Production in the United
States Pacific Northwest. Oregon State Universit. Online: www.extension.oregonstate.edu/catalog/html/sb/sb681/ (In English).

3. Baader W., Dohne E., Brenndörfer M. Biogas in Theorie 
und Praxis. Darmstadt: Kranichstein. 1982. 148 (In German). 4. Angelidaki I., Alves M., Bolzonella D., Borzacconi L., Campos J.L., Guwy A.J., Kalyuzhnyi S., Jenicek P., Lier J.B. Defining the biomethane potential (bmp) of solid organic wastes and energy crops: a proposed protocol for batch assays. Water Science \& Technology. 2009. 59(5). 927-934 (In English).

5. Lin J.G., Ma Y.S., Chao A.C., Huang C.L. BMP test on chemically pretreated sludge. Bioresour. Technol. 1999. 68(2). 187-192 (In English).

6. DubrovskisV., Plūme I., Kotel̦eņecs V., Zabarovskis E. Biogas production and biogas potential from agricultural biomass and organic residues in Latvia. Engineering for rural development. 2011. Vol. 10. 566-571 (In English).

7. Fernandez B., Porrier P., Chamy R. Effect of inoculumsubstrate ratio on the start-up of solid waste anaerobic digesters. Water Science \& Technology. 2001. 44(4). 103-108 (In English).

8. Leitfaden Biogas. Von der Gewinnung zur Nutzung. Online: http://www.fnr-server.de/ftp/pdf/literatur/pdf_208leitfaden_biogas_2010_neu.pdf(In German).

9. Joy J.E., Stanley J., Watson S.J., John A., Benson J.R. Marijuana and Medicine: Assessing the Science Base. Washington D.C: National Academy of Sciences Press. 1999. 256 (In English).

Конфликт интересов. Авторы заявляют об отсутствии конфликта интересов.
10. Kamat J., Roy D.N.M, Goel M.K.M Effect on harvesting age on the chemical properties of hemp plants. Journal of Wood Chemistry and Technology. 2002. N22(4). 285-293 (In English)

11. Struik P.C., Amaducci S., Bullard M.J., Stutterheim N.C., Venturi G., Cromack H.T.H. Agronomy of fibre hemp (Cannabis sativa L.) in Europe. An International Journal Industrial Crops and Products. 2000. 11. 107-118 (In English).

12. Thomas P., Svensson S., Andersson A., Mattsson J.E. Energy balances for biogas and solid biofuel production from industrial hemp. Biomass and Bioenergy. 2011. 35(7). 3040-3049 (In English).

13. Projektes „Handreichung Biogasgewinnung und -nutzung", Leitfaden Biogas. Von der Gevinnung zur Nutzung. 2010. 267 (In German).

14. Adamovičs A., Dubrovskis V., Plūme I., Jansons Ā., Lazdiña D., Lazdiņš A., Biomasas izmantošanas ilgtspējīibas kritēriju pielietošana un pasākumu izstrāde [Criteria for biomass use sustainability and development of measures]. Rīga: Vides projekti. 2009. 125-159 (In Latvian).

15. Pakarinen A., Maijala P., Stoddard F., Santanen A., Kymalainen M., Viikari L. Evaluation of annual bioenergy crops in the Boreal zone for biogas and ethanol production. Biomass and Bioenergy. 2011. 35(7). 3071-3078 (In English).

Conflict of interest. The authors declare no conflict of interest. 